\title{
Mitska krajina: uvod v različne perspektive
}

\author{
Katja Hrobat Virloget \\ Univerza na Primorskem \\ katja.hrobat@fhs.upr.si
}

\section{O poenoteni čezmejni turistični destinaciji Mitski park}

Knjiga, ki je pred vami, je eden izmed rezultatov mednarodnega projekta »Mitski park«, ki je kot zgleden primer nastal v sodelovanju med lokalno skupnostjo in stroko. ${ }^{1}$ Ideja o prezentaciji bogatega pripovednega izročila in arheoloških najdišč v rodiški krajini (Hrobat 2001) je bila razvita in natančneje začrtana v mednarodnem projektu "Living Landscape«, ${ }^{2}$ po neuspešni prijavi nadaljevanja projekta so iniciativo prevzeli Rodičani z Občino Hrpelje-Kozina, poiskali projektne partnerje in uspešno prijavili projekt.

Na območju Mošćeničke drage se je ideja o predstavitvi (pra)slovanske mitske krajine porodila že prej, postavljene so bile informativne table, tekom pričujočega projekta pa je bil namen nadgradnja prezentacije in poenotenje $\mathrm{z}$ Rodikom $\mathrm{v}$ enotno čezmejno turistično destinacijo Mitski park. $S$ prezentacijo mitskega in folkornega izročila in situ, tj. v krajini, v kateri je uprostorjeno, polagamo temelje ene najbolj edinstvenih izobraževalnih in izkustvenih turističnih destinacij v Evropi, saj gre za ene redkih primerov celostnega ohranjanja tovrstne nesnovne dediščine, ki je po večini Evrope, sploh v zahodni, izumrla.

Čeprav poenotene v enotno turistično destinacijo, sta si rodiška in trebiška mitska krajina nekoliko različni. V krajini okrog Rodika je prikazan nekakšen palimpsest tradicijskih verovanj oziroma pogledov na svet skozi čas oziroma sinkretična mitska krajina, ki sega skozi najrazličnejše ča-

\footnotetext{
${ }^{1}$ Mitski park. Skupna čezmejna turistična destinacija za ohranjanje, varstvo in promocijo dediščine mitske krajine/Zajednička prekogranična turistička destinacija za očuvanje, zaštitu i promicanje baštine mitskog prostora. Program sodelovanja Interreg V-A SlovenijaHrvaška 2014-2020. Projekt je sofinanciran iz sredstev E S S R.

${ }^{2}$ Program čezmejnega sodelovanja Slovenija-Italija 2007-2013 iz sredstev Evropskega sklada za regionalni razvoj in nacionalnih sredstev, vodja Aleksander Panjek, Univerza na Primorskem, Fakulteta za humanistične študije.
} 
sovne plasti, ki jih lahko grobo ločimo na krščansko in predkrščansko, pri čemer lahko korenine segajo še $\mathrm{v}$ čas staroselcev iz arheoloških najdišč, medtem ko je mitska steza v Trebišćih pri Mošćenički Dragi osredotočena na eno samo časovno oziroma tematsko raven, to je na rekonstrukcijo (pra)slovanske mitologije. Obe mitski krajini se razlikujeta tudi po svoji vsebini. Medtem ko rekonstrukcija (pra)slovanske mitologije v Trebišćih sloni v glavnem na analizi mitske toponomastike, kjer pripovednega izročila skorajda ni, je prezentacija v krajini Rodika osredotočena prav na bogato pripovedno izročilo, ki je prikazano in situ, torej v prostorskem kontekstu, iz katerega izhaja.

V obeh čezmejnih parkih so vzpostavljene učne poti po mitski krajini, po katerih bo lahko vodil posebej v projektu izobraženi turistični vodnik ali bodo obiskovalci na poteh samostojno poslušali interpretacije na G S M-ovi aplikaciji v slovenščini (z rodiškim narečjem), hrvaščini, angleščini in italijanščini (ali v Rodiku o tem prebrali v prilogah ob poti). Na Rodiškem bodo poleg izbrane povedke $z$ določenega mesta poslušali etnološko interpretacijo pripovednega izročila $v$ kontekstu krajine, v Trebišćih bodo poslušali strokovne interpretacije (pra)slovanske mitologije. Ker smo se v projektu želeli izogniti invazivnim tablam $\mathrm{v}$ naravi, bodo interpretacije in povedke nadgrajene $\mathrm{v}$ vizualni obliki, s kamnitimi skulpturami in kamnitimi označevalci, ki bodo iz lokalnega kamna, iz apnenca v kraškem okolju in iz peščenjaka na Brkinskem slemenu. ${ }^{3}$ Za najmlajše bo učna pot popestrena $\mathrm{z}$ interaktivnimi igrami, katerih rešitev bo odprla interakcije na razstavi $\mathrm{v}$ obeh centrih za obiskovalce, v Rodiku in v Trebišćih.

\section{Glavne vsebinske poteze Mitskega parka v Rodiku in v Trebišćih}

V rodiški krajini prezentacija sloni na bogatem pripovednem izročilu o določenih točkah v krajini, tudi o arheoloških najdiščih. Pripovedna izročila so predstavljena na listu mesta, od koder izhajajo, torej v originalnem prostorskem kontekstu. Pri tem je potrebno opozoriti, da je obiskovalcem predstavljena zgolj selekcija povedk, saj se na vsako točko navezujejo najrazličnejše zgodbe (Peršolja 200o). Izbrane so bile tiste povedke, ki s strokovnega stališča najbolj ponazarjajo etnološko interpretacijo določenega

\footnotetext{
${ }^{3}$ Vodja projekta oblikovanja kamnitih skulptur in označevalcev na slovenskem delu je bila Špela Šedivy iz Inkubatorja, d. o. o., pri čemer je sama izdelovala in bila hkrati tudi mentorica študentom programa oblikovanja kamna $z$ Višje strokovne šole v Sežani v okviru Izobraževalnega razvojnega središča. V Trebišćih sicer poleg novih oblik prezentacije in skulptur v avtorstvu akademskega kiparja Luba de Karina ostajajo še starejše napisne table avtorja Grge Frangeša.
} 
mesta v pokrajini. Sicer niso bile selekcionirane samo zgodbe, temveč tudi mesta; izbrana so bila le tista, ki se nahajajo v bližini že obstoječih stez, pa čeprav je krajina veliko bogatejša s pripovednim izročilom (Peršolja 2000; Hrobat 2010; Hrobat Virloget 2021).

V Rodiku se je, najbrž zaradi stika dveh različnih populacij, Slovanov in staroselcev iz arheološke naselbine Ajdovščina nad Rodikom, ohranilo bogato pripovedno izročilo, ki lahko sega globoko v preteklost. V Mitski park so vključena štiri arheološka najdišča, poleg Njivic, Tabora in Rodiške pečine s kaštelirjem Debela griža je najpomembnejša Ajdovščina nad Rodikom, prazgodovinski kaštelir (prazgodovinsko gradišče) in poznoantično naselje (obrambna postojanka). Zanimanje za arheološko naselje Ajdovščina nad Rodikom je zabeleženo že od 19. stoletja naprej, ko je bil v bližini najden epigrafski napis iz 1. stoletja n. št. $z$ imenom Rundictov, staroselcev, ki so jih strokovnjaki zaradi podobnosti imena pripisali Ajdovščini nad Rodikom. Obiskovalci se spoznajo z nenavadnimi izročili o mitskih ajdih z Ajdovščine, ki odražajo večtisočletni spomin na prednike in morda na sobivanje ter stike dveh populacij, staroselske in slovanske.

Mitsko-folklorna pot pohodnika popelje mimo dvanajstih točk, ki se nahajajo na nekdanjih mejah rodiške srenjske posesti ali ob glavnih vaških poteh. Zaradi bogate mitske krajine je pot (tako kot vas) razdeljena na dva dela, (zgornjo) brkinsko, ki smo jo poimenovali Lintverjev krog, in (spodnjo) kraško, ki smo jo imenovali Babin krog. Eden od glavnih likov poti je strašni lintver, kačon, ki so ga vaščani s krščanskim obredjem in procesijami kot hudiča izganjali ter skušali pomiriti, da ne bi pošiljal strel, neviht in poplav. Na Jezeru, kjer naj bi lintver prebival, tik nad grobiščem staroselcev z Ajdovščine nad Rodikom, izročila in antropogene dejavnosti verjetno nakazujejo kontinuiteto predkrščanskega (staroselskega?) kultnega mesta. Druga središča točka je (nekdanja) monolitna Baba, materialni ostanek verovanja $\mathrm{v}$ arhaični mitski ženski lik tako slovanskega kot romanskega izvora (Hrobat Virloget 2021). Na poti se v krajini odstirajo mesta vstopa v onstranstvo prek kraških brezen, kar je prikazano na primeru Globoke jame, ${ }^{4}$ Cikove in Fukove z izročili o samomorih, prehodu na drugi svet in zmaju, prvi lipi kot mitičnem drevesu ter coprniških srečanjih. Sledovi v naravni skali so dali povod za predstavo o šembilji, hudiču $z$ vozom, ki se zdi prežitek slovanskega gromovnika Peruna, božanstva groma in ognja.

${ }^{4}$ V vsej starejši literaturi je bila napačno imenovana Šlavrova jama, kar smo odkrili tekom pričujočega projekta. Njeno pravo ime je Globoka jama ali Jama v Borštu. Za to informacijo se zahvaljujem Valeriji Pučko in Zvonetu Lukovcu. 
To mesto je eno izmed številnih mest vzdolž rodiške srenjske meje (Kobilja glava, Njivice, Križen drev, Robida), na katerih se pojavljajo bajeslovna bitja, prikazni, kjer se videvajo duše, ki se vicajo, kjer kovač ubija popotnike, kjer straši krvavo stegno, kjer je grob ubitih vojakov, kjer kače stražijo zaklade, kjer kače izginejo $v$ neznano po magičnem obredu, kjer čarovnice $\mathrm{v}$ divjem plesu raztrgajo vedamca, kjer volk ubije kobilo, kjer zakleta kača čuva ruševine gradu itd. (Hrobat Virloget 2020).

Mitska steza v Trebišćih pri Mošćenički Dragi s trinajstimi lokacijami informacijskih tabel je za razliko od sinkretičnega mitskega in folklornega izročila v Rodiku osredotočena na rekonstruirano zgodbo (pra)slovanske mitologije v glavnem na osnovi mitskih toponimov, in sicer hriba Perun in zaselka Trebišća. Pripovednega izročila je zelo malo in se navezuje na točko pod hribom Perun, ki je bila prepoznana kot Velesova. Na poti je prikazana celotna rekonstruirana mitska zgodba (pra)slovanske mitologije, pri čemer so le zgoraj omenjeni toponimi in situ, na ostalih delih poti pa se razvija mitska zgodba, ki ni povezana $\mathrm{z}$ določenimi mesti v krajini (Hrobat Virloget 2020; 2021).

Ime Perun priča o sveti gori najvišjega slovanskega nebeškega božanstva - Peruna; njegovo dejanje povzročanja nevihtnega grmenja z mlinskimi kamni je postavljeno $\mathrm{v}$ mlin $\mathrm{v}$ Trebišćih, čigar ime priča o mestu za žrtvovanje (»treba« pomeni staroslovansko žrtev), torej prinašanja darov Perunu na gori v njenem vznožju. Velesovo mesto je prepoznano v Voloskem kuku, v steni in jamah na izviru Potoka pod vasjo Potoki, kjer se s tipičnim mestom v krajini za božanstvo imetja in mrtvih ujema tudi izročilo o hudiču, kot je Veles $v$ krščanstvu pogosto upodobljen. $V$ tem primeru imamo vse elemente osnovne (pra)slovanske mitologije: Perun na vrhu, izpod njega, ob vznožju gore, ob vodi Veles in mesto žrtvovanja v Trebišćih (Katičić 2008, 305-312; Hrobat Virloget 2021). Nadaljevanje zgodbe o mitski svatbi Perunovih otrok (Mare in Jurija/Ivana) je sicer nakazano na (starejših) interpretacijskih tablah z namenom poučevanja, vendar ne izhaja iz in situ mitske toponomastike in izročila.

Poudariti je potrebno, da v Evropi nimamo ohranjenih mitov, to je celotnih mitskih tekstov, povezanih z obredi, temveč so se ohranili le drobci verovanj, ki jih zato imenujemo mitsko izročilo. Iz teh drobcev so etnologi in arheologi poskušali rekonstruirati izvorno (pra)slovansko mitologijo oziroma mitično zgodbo, pri čemer se je potrebno zavedati, da so to le poskusi rekonstrukcij. V Trebišćih je tako predstavljena le ena izmed znanstvenih rekonstrukcij slovanske mitologije, ki sledi analizam mitske toponomastike hrvaških raziskovalcev - (pokojnega) Radoslava Katičića 
in Vitomirja Belaja (Hrobat Virloget 2021). Obiskovalci se spoznajo tudi z zgodovino Slovanov in pri cerkvi sv. Petra spoznajo, kako je bila stara vera Slovanov pokristjanjena. Na Počivalih na stezi Petrebišća (drugo mesto možnih darovanj) Voloski kuk (mesto Velesa) je prikazana tretja oseba (pra)slovanskega izročila, to je Mokoš ali Baba, ki tudi ni prisotna na mitski stezi in situ (Katičić 2008, 305-312; Belaj in Belaj 2014; Hrobat Virloget 2021).

Glavna mitska lika, Baba v rodiški in Perun v trebiški krajini, sta kot slovanski nebeški božanskipar v (pra)slovanski mitski zgodbi tista, ki park vsebinsko povezujeta. Simbolizirana sta v logotipu Mitskega parka. ${ }^{5} \mathrm{Baba}$ je stilizirana amorfna oblika s krogi, ki ponazarjajo ženske prsi, Perun je stiliziran element mlinskega kamna, s katerim proizvaja strele in grome. Rdeča barva logotipa ponazarja nebeško božanstvo Peruna, njegov ogenj, blisk, ognjevitost. Siva barva simbolizira Babo, kamen, mati zemljo in je hkrati barva Krasa in Istre, kjer se nahajata oba dela Mitskega parka.

\section{O vsebini knjige}

Ideja knjige sloni na konceptu razstave v Centru za obiskovalce v Rodiku z naslovom "Mitske in druge resničnosti,${ }^{6}{ }^{k i}$ problematizira različne poglede na svet, lahko bi rekli tudi različne percepcije sveta, različne kulturne konstrukcije resničnosti oziroma v angleščini world-makings (van der Port in Meyer 2018, 2). Različni pogledi na svet se razlikujejo skozi čas, vendar tudi soobstajajo kot dominantni in marginalizirani diskurzi, kot, recimo, svet skozi oči znanosti ali različne verovanjske predstave, med drugim danes prevladujoča new age (Hrobat Virloget 2021). Ena izmed interpretacij sveta je tudi umetniška, ki jo na razstavi prikazuje U N E S C O-v umetnik za mir Marko Pogačnik, ki v svoji umetnosti operira s še eno drugo resničnostjo, to je skozi pogled geomantije (Pogačnik 2020). Poleg te percepcije na razstavi sledimo tudi drugim različnim interpretacijam mitske krajine, in sicer skozi oči različnih znanosti in mitskega pogleda, ki je za razliko od stanja $\mathrm{v}$ sodobni družbi postavljen $\mathrm{v}$ prvi plan.

Knjiga sledi vsebinskemu konceptu soočanja različnih resničnosti, vendar tokrat le v okviru znanstvenega diskurza. Mitska krajina in pripovedno izročilo, predvsem s poudarkom na Rodiku, sta v pričujoči znanstveni mo-

\footnotetext{
${ }^{5}$ Avtorica logotipa je oblikovalka Manca Švara.

${ }^{6}$ Avtorice vsebinskega koncepta razstave in besedil smo Katja Hrobat Virloget, Ana Plestenjak in Neža Čebron Lipovec, oblikovalci so Zavod t R A N S, Sanja Jurca Avci, Tomaž Budkovič in Dolores Gerbec, vse pod finančnim nadzorom Ester Mihalič iz Občine Hrpelje-Kozina.
} 
nografiji analizirana z vidika različnih strok: etnologije, arheologije, zgodovine, geografije in dediščinskih študijev. Katja Hrobat Virloget, idejna avtorica Mitskega parka, nadgrajuje dosedanje analize mitskih krajin okrog Rodika in Trebišć, na osnovi katerih je že bil postavljen park, predvsem z vprašanji kolektivnega spomina $v$ prostoru, bistva verovanj in "nadnaravnega«, plastenja različnih verovanjskih izročil skozi čas v krajini ter z novimi spoznanji analize obeh mitskih krajin. V zaključku poglavja so zapisane smernice in nekateri problemi pri upravljanju z mitsko nesnovno dediščino parka. Zgodovinar Aleksander Panjek obravnava ruralno zgodovino Rodika $z$ vidika gospodarstva, družbe in okolja 19. stoletja, kar nadgrajuje z izvirno analizo zgodovinske kontekstualizacije pripovednega izročila o preselitvi mitskih ajdov v Rodik in posledično delitve vasi, ki se je do nedavnega izražala v ustnem izročilu ter šegah in navadah. $V$ članku s pomenljivim naslovom »Arheologija spomina "Massimo Medeot, Mario Crevato in Alja Margon podajo arheološko topografijo rodiške krajine s posebnim poudarkom na pripovednem izročilu o arheoloških najdiščih in krajini, pri čemer prikažejo tudi novoodkrita arheološka najdišča. $Z$ vidika geografije rodiško mitsko krajino obravnava Gregor Kovačič. Posebej pozoren je na mesta domovanja lintverja $\mathrm{Na}$ Jezeru ter izročil s Kobilje glave in skalo v obliki konjske glave, na šembiljine kolesnice in hudičev stol Pod lisičino in Ajdovščino. Monografija se zaključuje z razpravo Neže Čebron Lipovec o problemih pri upravljanju Mitskega parka kot kompleksne kombinacije nesnovne in materialne dediščine, kar $\mathrm{v}$ tem prostoru predstavlja novost in poseben izziv.

\section{Literatura}

Belaj, V., in B. Belaj. 2014. Sveti trokuti: topografija hrvatske mitologije. Zagreb: Matica hrvatska.

Hrobat, K. 2010. Ko Baba dvigne krilo: prostor in čas v folklori Krasa. Zbirka Razprave. Ljubljana: Znanstvena založba Filozofske fakultete.

—. 2020. "Mitsko izročilo Mitskega parka.«V Mitski park: priročnikza izobraževanje; skupna čezmejna turistična destinacija za ohranjanje, varstvo in promocijo dediščine mitske pokrajine območja, ur. K. Hrobat Virloget, J. Đurkin Badurina, J. Rudan, N. Brubnjak, Š. Šedivy, E. Mihalič, E. Matijašić in A. Plestenjak, 3-27. http://mitski-park.eu/wp-content/uploads/ 2020/o9/FINAL-Priro\%C4\%8Dnik207A6120697A6F627261C5BE657661 6E6A65202D204D6974736B69207061726B2E706466.pdf

Hrobat Virloget, K. 2021. „Mitska krajina: razmisleki in smernice za mitski park.«V Mitska krajina: iz različnih perspektiv, ur. K. Hrobat Virloget, 1755. Koper: Založba Univerze na Primorskem. 
Katičić, R. 2008. Božanski boj: tragovima svetih pjesama naše pretkršćanske starine. Zagreb: Ibis grafika; Moščenićka draga: Katedra Čakavskog sabora Općine Mošćenička Draga.

Peršolja, J. M. 200o. Rodiške pravce in zgodbe. Ljubljana: Mladika.

Pogačnik, M. 2020. Elementarne sile in bitja Rodika. Ljubljana: Društvo za sožitje človeka, narave in prostora Vitaa.

van der Port, M., in B. Meyer. 2018. »Introduction: Heritage Dynamics; Politics of Authentication, Aesthetics of Persuasion and the Cultural Production of the Real."V Sense and Essence: Heritage and the Cultural Construction of the Real, ur. M. van de Port in B. Meyer, 1-39. New York: Berghahn.

\section{Mitska krajina: uvod v različne perspektive}

V uvodu knjige so predstavljene osnovne značilnosti mitske krajine v Rodiku in v Trebišćih pri Mošćenički dragi, ki se povezujeta v enotno čezmejno turistično destinacijo. Pokazane so skupne lastnosti, to je mitsko izročilo v krajini in situ v obliki pripovednega izročila in toponimov. Po drugi strani tudi izvemo, v čem se parka razlikujeta: medtem ko v Trebišćih izročilo temelji na mitskih toponimih in skorajda ni pripovednega izročila, je slednje bistvo parka v Rodiku, kjer so zgodbe predstavljene na mestih v krajini, iz katerih izhajajo in ki jih pojasnjujejo. Medtem ko v Trebišćih spoznavamo (pra)slovansko mitsko krajino, je v Rodiku prikazan palimpsest različnih pogledov na svet oziroma sinkretična mitska krajina. V projektu smo se izognili invazivnim tablam in namesto teh mitske točke predstavili na G S M-ovi aplikaciji ali v pisni obliki, po mitski poti vodijo kamniti označevalci, zgodbe pa so interpretirane na kamnitih skulpturah. Najmlajše spremljajo interaktivne igre, katerih rešitev odpre interakcijo v centrih za obiskovalce v Rodiku in $\mathrm{v}$ Trebišćih.

V Rodiku prevladujejo izročila, ki pojasnjujejo prostor in ga označujejo, od mitskih ajdov, mitske Babe, šembilje do vstopov v onstranstvo prek jam itd. Na poti v Trebišćih spremljamo rekonstrukcijo (pra)slovanske mitske zgodbe. Pri tem je potrebno opozoriti, da imamo ves čas opravka z mitskim izročilom, torej z drobci nekih mitskih verovanj, ki so se ohranili v ljudskem izročilu, in ne $z$ miti, ki se v Evropi kot sveti teksti niso ohranili. Park v enotno destinacijo povezujeta Perun nad Trebišći in Baba v Rodiku, slovanski božanski mitski par, ki sta upodobljena v logotipu projekta Mitski park.

Na koncu je nakazana vsebina knjige, ki sledi konceptu razstave v Rodiku o različnih pogledih na svet oziroma percepcijah sveta. Ti se menjujejo skozi čas, lahko pa tudi soobstajajo kot dominantni in marginalizirani diskurzi. Na razstavi mitsko krajino spremljamo skozi oči znanstvenega diskurza, mitskega izročila in umetniške vizije preko geomantične raziskave umetnika Marka Pogačnika. Različnim vidikom iste stvarnosti sledi tudi koncept 
knjige, vendar omejujoč se le na znanstveni diskurz. V njej je mitska krajina, predvsem izhajajoč iz Rodika, predstavljena skozi različne znanstvene perspektive, od etnološke, zgodovinske, arheološke in geografske do vidika dediščinskih študij.

\section{Mythical Landscape: Introduction into Different Perspectives}

The introduction to the book includes basic features on the mythical landscape oft Rodik and Trebišće near Mošćenička Draga, which have been combined to create a joint cross-border tourist destination. Their common features are presented, i. e. the mythical tradition in the landscape in situ, in the form of narrative tradition and toponyms. On the other hand, we discover the difference between the two parks: while in Trebišće the tradition is based on mythical toponyms, and the narrative tradition is almost non-existent, it is a fundamental feature of the park in Rodik where stories are presented in the places from where they originate and explain them. In Trebišće, we get to know the (old) Slavic mythical landscape, while in Rodik the palimpsest of different views of the world or syncretic mythical landscape is presented. In the project, we avoided using the usual information boards by presenting the mythical landscape points through a GSM app or in written form, stone markers guide along the mythical paths, and stories are interpreted in stone sculptures. The youngest visitors can engage in interactive games where solutions open interaction points in the visitor centres at Rodik and Trebišće.

In Rodik prevail traditions that interpret and mark this space - from the mythical Ajdi, the mythical Baba, 'Šembilja,' to the entrance to the world of the dead through caves, etc. On the mythical path around Trebišce we follow the reconstruction of the (old) Slavic mythical story. It should be noted that we deal exclusively with the mythical tradition, i. e. fragments of some mythical beliefs preserved in folklore, and not myths as sacred texts which have not been preserved in Europe. Perun above Trebišće and Baba from Rodik, the Slavic divine mythical couple depicted in the logo of the Mythical Park project, represent the common feature that connects the two locations to create a joint tourist destination. ${ }^{7}$

At the end the content of the book is indicated which follows the concept of the exhibition in Rodik on the different views or perspectives of the world.

\footnotetext{
${ }^{7}$ Mythical park. Joint cross-border tourist destination for the preservation, protection and promotion of the heritage of the mythical area. Interreg V-A Slovenia-Croatia Co-operation Programme 2014-2020. The project is co-funded by the ER D F. Project duration: 1 September 2018-30 February 2021. Project holder: Municipality of Hrpelje-Kozina; project partnership: Municipality of Mošćenička Draga, University of Rijeka, Faculty of Tourism and Hospitality Management; Inkubator, d. o. o.; University of Primorska/Università del Litorale; Tourist Board of Mošćenička Draga; Arhej, d. o. o., archaeological research and other intellectual services.
} 
These can change over time, and may coexist as dominant and marginalised discourses. On the exhibition we follow the mythical landscape through scientific discourse, mythical tradition and artistic vision through the geomantic research of the artist Marko Pogačnik. The concept of the book also follows different aspects of the same reality, but limiting itself only to scientific discourse. The mythical landscape, especially in the case of Rodik, is presented through various scientific perspectives - ethnological, historical, archaeological, and from the point of view of heritage studies.

\section{Mitski prostor: uvod u različite perspektive}

Uvod u knjigu predstavlja osnovne značajke mitskog krajolika u Rodiku i u Trebišćima kod Mošćeničke Drage, koje su povezane u zajedničku prekograničnu turističku destinaciju. Prikazana su njihova zajednička obilježja, odnosno mitska tradicija u krajoliku in situ, i to u obliku narativne tradicije i toponima. S druge strane, doznajemo po čemu se ova dva parka razlikuju: dok se u Trebišćima predaja temelji na mitskim toponimima, a narativna tradicija gotovo da i ne postoji, ona je temeljna značajka parka u Rodiku, gdje su priče predstavljene na lokacijama u krajoliku iz kojih potječu i koje ih pojašnjavaju. Dok u Trebišćima upoznajemo (pra) slavenski mitski krajolik, u Rodiku je prikazan palimpsest različitih pogleda na svijet odnosno sinkretični mitski krajolik. U projektu smo izbjegli korištenje uobičajenih informativnih ploča tako što smo mitske punktove predstavili putem GSM aplikacije ili u pisanom obliku, uzduž mitskih staza postavljeni su kameni markeri, a priče se tumače u kamenim skulpturama. Najmlađe posjetitelje prate interaktivne igre čije rješenje otvara interakciju u Centrima za posjetitelje u Rodiku i u Trebišćima.

U Rodiku prevladavaju predaje koje tumače i obilježavaju taj prostor - od mitskih Ajda, mitske Babe, šembilje do ulaza u svijet mrtvih kroz špilje itd. Na putu oko Trebišća pratimo rekonstrukciju (pra) slavenske mitske priče. Pritom valja napomenuti da se cijelo vrijeme bavimo isključivo mitskom tradicijom, odnosno fragmentima nekih mitskih vjerovanja sačuvanih u narodnoj predaji, a ne mitovima koji u Europi nisu sačuvani kao sveti tekstovi. Park povezuju u zajedničku destinaciju Perun iznad Trebišća i Baba iz Rodika, slavenski božanski mitski par koji je prikazan u logotipu projekta Mitski park. ${ }^{8}$

\footnotetext{
${ }^{8}$ Mitski park. Skupna čezmejna turistična destinacija za ohranjanje, varstvo in promocijo dediščine mitske krajine/Zajednička prekogranična turistička destinacija za očuvanje, zaštitu i promicanje baštine mitskog prostora. Program suradnje Interreg V-A Slovenija-Hrvatska 2014-2020. Projekt sufinancira E R D F. Trajanje projekta: 1. rujan 2018-30. veljača 2021. Nositelj projekta: Općina Hrpelje-Kozina; projektno partnerstvo: Općina Mošćenička Draga, Sveučilište u Rijeci, Fakultet za menadžment u turizmu i ugostiteljstvu; Inkubator, d. o. o.; Univerza na Primorskem/Università del Litorale; Turistička zajednica općine Mošćenička Draga; Arhej, d. o. o., arheološke raziskave in druge intelektualne storitve.
} 
Na kraju je naznačen sadržaj knjige koji prati koncept izložbe u Rodiku o različitim pogledima na svijet, odnosno različitim doživljajima svijeta. Oni se s vremenom mijenjaju, a mogu i koegzistirati kao dominantni i marginalizirani diskursi. Izložba prati mitski krajolik kroz znanstveni diskurs, mitsku tradiciju i umjetničku viziju kroz geomantijska istraživanja umjetnika Marka Pogačnika. Koncept knjige prati i različite aspekte iste stvarnosti, ali ograničavajući se samo na znanstveni diskurs. Mitski krajolik, posebno u slučaju Rodika, u knjizi se prikazuje kroz različite znanstvene perspektive etnološke, povijesne, arheološke i zemljopisne te sa stajališta proučavanja baštine. 